\title{
Influence of Family Size, Nature of Job and Years in Marriage on Working Mothers Job Commitment in Public Universities in South-West Nigeria
}

\author{
Ngozi Uwannah* \\ Department of Education, Babcock University, Ilishan-Remo, Ogun State, Nigeria.
}

\begin{abstract}
Several researchers have worked on variables that affect working mothers' job commitment in Nigeria, but little research have been carried out to determine the influence that family size, years in marriage and nature of job have on their job commitment, hence the need for this study which investigated the influence of family size, nature of job and years in marriage on working mothers' job commitment in public universities in South-West Nigeria. Four null hypotheses guided the study and research design of the ex-post facto type was employed. Nine hundred and fifty working mothers were drawn from three federal and three state public universities in South-West Nigeria through the multi-stage random sampling technique. The data collected was analysed using frequencies, simple percentages and multiple regression analysis and the level of significance was set at $0.05 \%$. Result of analysis revealed a significant combined influence of family size, nature of job and years in marriage on working mothers' job commitment with nature of job as the strongest predictor of job commitment. It was further revealed that the job commitment of working mothers in public universities in south-west Nigeria is low. Based on the results, it was recommended that university management should cater for the welfare of working mothers based on their unique needs.
\end{abstract}

Keywords: Family Size, Nature of Job, Years in Marriage, Job Commitment

DOI: $10.7176 / \mathrm{JEP} / 10-6-18$

\section{Introduction}

Every organization want to be successful in terms of satisfying the needs of their stakeholders as well as increasing profit. To this end, educational institutions have a dire need for a committed workforce that will engineer them towards achieving their set goals. When workers are committed, they will co-operate with management, their supervisors as well as colleagues to ensure organizational effectiveness. However, the presence of women in organizations today which is global and Nigeria not an exception, suggest that some factors related to family and caring may likely encroach into their level of commitment towards their job. It is no gainsaying that caregiving responsibilities affect women's job commitment (Workplace Fairness Report, 2019) and that most women who engage in paid work, do so mainly for financial reasons (Austen \& Birch, 2000).

Several studies have looked at working mothers with respect to some aspects like their job performance, familywork conflict, family/work variables (Patel, Vasanthee, Paruk \& Ramgoon, 2006); factors that affect their worklife balance such as family size, age of children, work hours and level of social support received (Reddy, Vranda, Ahmed, Nirmala \& Siddaramu, 2010) and numerous others. This is because caregiving responsibilities affect working women (Workplace Fairness Report, 2019) and the number of children they have to cater for, the type of work they do which to a great extent will determine the degree of flexibility available to them and how long they have been married may have influence which may affect their commitment. It is therefore based on the above, that this study looked at the influence that family size, nature of job and years in marriage have on working mothers' job commitment in public universities in South-West, Nigeria.

\subsection{Purpose of the Study}

The main objective of this study is to examine the influence of family size, nature of job and years in marriage on working mothers' job commitment in public universities in South-West, Nigeria. Specifically, the study aims at:

i) Finding out the level of job commitment among working mothers in public universities in South-West, Nigeria.

ii) Establishing the variable that contributed mostly to working mothers' job commitment in public universities in South-West, Nigeria. 
iii) Determining the combined influence of family size, nature of job and years in marriage on working mothers' job commitment in public universities in South-West, Nigeria.

iv) Examining the relative influence of family size, nature of job and years in marriage on working mothers' job commitment in public universities in South-West, Nigeria.

\subsection{Research Questions}

i) What is the level of working mothers' job commitment in public universities in South-West, Nigeria?

ii) Which variable (family size, nature of job, years in marriage) contributed mostly to the working mothers' job commitment in public universities in South-West, Nigeria?

\section{$1.4 \quad$ Research Hypotheses}

i) There is no significant combined influence of family size, nature of job and years in marriage on working mothers' job commitment in public universities in South-West, Nigeria.

ii) Family size will not significantly influence the job commitment of working mothers in public universities in South-West, Nigeria.

iii) Nature of job will not significantly influence the job commitment of working mothers in public universities in South-West, Nigeria.

iv) Years in marriage will not significantly influence the job commitment of working mothers in public universities in South-West, Nigeria.

\subsection{Job Commitment}

Commitment is an important variable studied in relation to business success (Erdheim, Wang \& Zickar, 2006). Several authors, though they accept that commitment is very vital to organisational success, look at it from different angles concluding that the focus of commitment can be to the organisation, to the goals of the organisation, to the union or to the occupation (Arciniega \& Gonzalez, 2011) while an employee can also choose to be committed to his or her career (Blau \& Boal, 1987; Gupta, 2011). According to Kiyak, Namazi \& Kahana, (2011), commitment is an employee's attachment to the entire organisation, an organisational subunit, a supervisor or even a change program. People in general work in order to earn a living and women are not an exception. The extent to which working mothers are committed to their jobs is affected by numerous variables of which some of them are identified in this research as family size, years in marriage and nature of job.

Job commitment is the extent at which employees are psychologically absorbed in their work activities (Sanders, n.d.). According to Gigli (2018) job commitment is a feeling of responsibility that is said to occur when a worker sees himself as responsible towards the achievement of the goals of organization. It is therefore believed that this feeling of responsibility pushes him to carry out tasks that will help the organization achieve their set goals. Committed employees have stronger work ethics, they go extra miles in their jobs by taking extra tasks and even staying beyond the formal closing time (Heibutz, 2018). The above comment point to the fact that committed employees take their jobs seriously and strive for excellence as well so as to maximize productivity for their organizations. On the other hand, Gigli (2018) observes that employees whose commitment are low, only work and do not put their heart into their work but are only concerned about their personal welfare.

In like manner, a working mother may have the desire to work and put in extra energy but may sometimes become constrained as she most times find herself struggling to juggle the competing demands of work and family and this excessive pressure and limited free time to handle all the roles may adversely affect her ability to cope. Along this line of thought, O'Laughlin and Bischoff (2005) assert that this experience can lead to workfamily conflict, job dissatisfaction, absenteeism, poor personal relations, and decreased work performance and all these are detrimental to achieving organizational set goals.

An ambitious working mother, just like her male colleagues may want to be totally committed to her job but the number of children she will have to cater for may thwart her efforts especially when she does not receive any support from her husband or the organisation. Hence, family size can influence the level of job commitment of working women (Lumley, Coetzee, Tladinyane \& Ferreira, 2011). Observation show that a working woman with more number of children or large family size may experience more role conflict than the one with small family size and this is compounded by the existing situation in Nigerian pubic workplaces today where there are no support for working mothers in terms of built-in crèche, extended maternity leave and flexibility in work schedule.

In the same way, Greenhaus and Powell (2003) suggest that young mothers with less experience in marriage may have weaker commitment to work since they will be struggling to adjust to their marital life, care-giving as well as their jobs. Also nature of people's job can affect their job commitment. The level of job commitment among 
teaching and non-teaching staff in Nigerian universities may be different because while teaching staff have flexibility in their starting and closing time, non-teaching staff may not and this may likely affect their job commitment.

\section{$2.2 \quad$ Family Size}

The Kerman English Multilingual Dictionary (2013) defines a family as a man, his wife and their children. Family size therefore refers to the number of people in a family. In this study, family size refers to the number of children in a home. The size of a working mother's family, may determine her level of job commitment, her level of job satisfaction as well as the existence or non-existence of work-family conflict. Due to the importance of this aspect of a working woman's life, various authors have looked at the effect of family size on the working mother's job commitment and satisfaction. Reddy, Ahmed, Nirmala and Siddaramu (2010) posit that family size and age of children are some of the determinants influencing the level of work-family conflict because of its consequence on psychological distress and well-being among working mothers. It has been reported that women with children are significantly lower in job commitment compared to women without children while women with younger children perform less compared with women with older children (Reddy, Vranda, Ahmed, Nirmala and Siddaramu, 2010). Ajayi, Ojo and Mordi (2015) while researching on work-family balance among women in selected banks in Lagos State Nigeria came up with the assertion that employees with significant dependent care responsible for caring for young children; employees with large family sizes and employees with dependent elders to care for report high levels of work-family conflict and are likely to be affected negatively in their work commitment and satisfaction. Further in her studies, Ajayi (2013) confirmed that previous researches on this field show that having preschool children is highly associated with role strain and time constraint for women. Catering for children at their tender ages bring more experience of work-family conflict among mothers because such children require more time and attention from their mothers, increases the more time their mothers spend with them and the more time she spends with them, the less time she spends doing her job and more negative feeling about her job (Ajayi, Ojo \& Mordi, 2015). Based on the strenuous roles of attending to the unending needs of children, one can conclude as well that working mothers with large family sizes may not be committed to their jobs since it has been reported that women with multiple roles report more physical exhaustion and psychological tension than women with less roles. Therefore, it is expected that working mothers with less number of children will be better committed than working mothers with many children because once her energy is exhausted over family roles of caring for children, less energy will be reserved for work activities.

\subsection{Nature of Job}

Every university aims at achieving efficiency and effectiveness through a team of committed and satisfied staff. Job commitment of employees is very crucial because of its relationship to organizational effectiveness. Working mothers who are not committed are likely to quit their jobs and according to Nawi, Ismail, Ibrahim and Raston (2016) job commitment is also related to job and life satisfaction and lowered job satisfaction is believed to affect the morale and turnover of academic and non-academic staff. Therefore for the university to enhance commitment so as to achieve efficiency among staff, the coordination of all resources which include both the teaching and non-teaching staff is necessary. Teaching and non-teaching employees perform various assignments which sometimes overlap and create conflicts. When the roles that employees perform are clear, the employees become satisfied and committed to their jobs but facing greater role ambiguity create conflict. Adekola (2012) expresses that unmet expectations, job characteristics, are some of the factors related to the job commitment of employees in an organization.

The studies of Akpan (2012) reveal that the job commitment of teaching staff relates to their condition of service and fringe benefits. His study identified recognition, salaries, welfare packages and good office accommodation as criteria that motivates and boosts the morale of academic staff in Nigerian public universities. However, Adeboyeye (2000) as cited in Akpan (2012) appreciates the fact that well managed infrastructural facilities and equipment enhances good teaching practices and facilitates learning. Regrettably, today, most of the offices of the lecturers are not furnished, the condition of work are also poor. This may be impacting negatively on their job commitment.

In comparing the level job commitment between female academic and non-academic staff of public universities in Nigeria, Oladosu and Adeniji (2015) observe that female teaching staff stick more to their jobs unlike their non-teaching counterparts that quit on short notices and go in search of jobs with better organizational support. The implication of this is that the non-teaching staff may experience more work-family conflict than the teaching staff. This is supported by the claims of Noonan, Rippeyoung and Glass (2007) who submitted that women in 
non- teaching jobs experience more role conflict than their teaching counterparts probably because they work more number of hours every week, have inflexible work schedules, frequent occurrence of overtime, difficult supervisors and work atmosphere that is not conducive and supportive of work and family life. Due to this fact, non-teaching staff are therefore more likely to be less committed than teaching staff.

\subsection{Years in Marriage}

Marriage and taking care of children has been discovered to affect women's job commitment. Studies have shown that young women's work commitment is high and relatively stable over time. Noonan et al (2007) discovered that commitment to work among women decreases after marriage but increases after childbirth. This indeed means that newly married mothers may need a lot of improved family friendly policies from their organizations in order to be committed and that is why women who are married with children are believed to take on less demanding jobs with less pay so as to combine effectively their work and family roles. This implies that single women may have more time and energy to engage in demanding jobs and may therefore achieve greater advancement in their career than married women with young children (Beauregard, 2007). Noonan et al (2007) also found that newly married women may have higher level of continuance commitment because of a financial need to work just because of high unemployment rate and not because they are happy doing their jobs. They also discovered that length of time in marriage is associated with lower levels of family commitment and higher levels of work commitment.

\section{Methodology}

This study adopted the descriptive research design of the Ex-post Facto type because variables were not manipulated rather the influence of already existing independent variables (family size, nature of job, years in marriage) on the dependent variable (job commitment) were observed. Nine hundred and fifty working mothers from six public universities (three federal and three State) in South-West Nigeria were selected through the multi-stage random sampling technique as participants. Job commitment was measured using the scale termed "investment model" developed by Farrell \& Rusbult in 1981 which comprised of 24 items with 9 options, for example: "how long would you like to stay at this job?" $1=$ short period of time and $9=1$ long period of time. The authors measured the reliability index four times and obtained high index showing the first time, $0.88,0.92$ the second time, 0.92 the third time and 0.93 the fourth time. Family size, nature of job and years in marriage were measured from information obtained from the demographics. The data collected were analysed using frequencies, simple percentages and multiple regression analysis and the level of significance was set at $0.05 \%$.

\section{RESULTS}

4.1 Table 1: Demographic information

\begin{tabular}{|l|l|l|l|l|}
\hline S/N & Variable & Category N=950 & Frequency & Percentage (\%) \\
\hline 1 & Family Size & $1-4$ & 542 & 57.0 \\
& & 5 \& Above & 408 & 43.0 \\
\hline 2 & Nature of Job & Teaching & 309 & 32.5 \\
& & Non-Teaching & 641 & 67.5 \\
\hline 3 & Years in Marriage & $0-10$ & 503 & 52.9 \\
& & $11 \&$ Above & 447 & 47.1 \\
\hline 4 & Age (years) & $18-25$ & 157 & 16.5 \\
& & $26-40$ & 513 & 54.0 \\
& & $41-50$ & 190 & 20.0 \\
& & $51 \&$ Above & 90 & 9.5 \\
\hline 5 & Marital Status & & & 70.0 \\
& & Married & 665 & 8.0 \\
& & Separated & 76 & 12.0 \\
& & Divorced & 95 & 10.0 \\
\hline
\end{tabular}




\begin{tabular}{|l|l|l|l|l|}
\hline 6 & Academic Qualification & FSLC/SSCE & 95 & 10.0 \\
& & ND/NCE & 290 & 30.5 \\
& & HND/Degree & 308 & 32.5 \\
& & Master's Degree & 157 & 16.5 \\
& & & 100.5 \\
\hline 7 & WhD & & \\
& & $0-5$ & 157 & 16.5 \\
& & $6-10$ & 280 & 29.5 \\
& & $11-15$ & 242 & 15.5 \\
& & $16-20$ & 147 & 13.0 \\
\hline
\end{tabular}

Results of the analysis of the demographic data of the participants presented in Table one revealed that a majority of the participants $(57 \%)$ had a family size of $1-4$ while $43 \%$ of the participants had a family size of 5 and above. Regarding nature of job, a majority of the participants $(68 \%)$ were non-teaching staff while $32 \%$ of the participants were teaching staff. Furthermore, a majority of the participants $(53 \%)$ has spent $0-10$ years in marriage while $47 \%$ of the participants has spent 11 years and above in marriage. A majority of the participants $(54 \%)$ were $26-40$ years old. This was successively followed by those who were $41-50$ years old $(20 \%), 18-$ 25 years old $(17 \%)$, and 51 years and above $(9 \%)$. The greatest proportion of the participants $(70 \%)$ were married, those who were divorced (12\%), widowed (10\%), and separated $(8 \%)$. The greatest majority of the participants $(33 \%)$ had HND/First degree academic qualification. This was successively followed by those with ND/NCE (30\%), Master's Degree (17\%), PhD (10\%), and FSLC/SSCE (10\%). Finally, the greatest proportion of the participants $(30 \%)$ had $6-10$ years of working experience in the university. This was followed by those who had $11-15$ years $(25 \%), 0-5$ years $(17 \%), 16-20$ years $(15 \%)$, and 21 years and above $(13 \%)$.

\subsection{Research Question One:}

What is the level of job commitment of working mothers in public universities in South-West Nigeria?

Table 2: Level of Working Mothers Job Commitment

\begin{tabular}{|l|l|l|}
\hline Level & Frequency & Percentage (\%) \\
\hline High & 451 & 47.5 \\
Low & 499 & 52.5 \\
\hline
\end{tabular}

Results in Table 2 indicated that for a majority of working mothers who participated in the study (53\%), the level of job commitment is low, while for the minority $47 \%$ of the participants, the level of job commitment is high. This result highlights the need to enhance job commitment among working mothers in Nigerian universities.

\subsection{Research Question Two:}

Which demographic variable (family size, nature of job, years in marriage) contributed mostly to the working mothers' job commitment in public universities in South-West, Nigeria?

Table 3: Coefficients of the Multiple Regression Analysis for the Relative Contribution of Family Size, Nature of Job, and Years in Marriage to Job Commitment

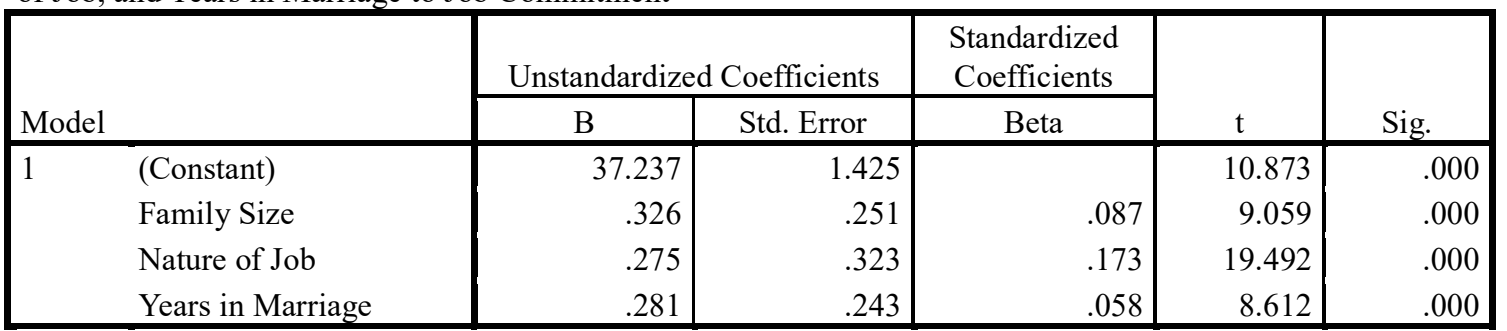

a. Dependent Variable: Job Commitment

Results in Table 3 revealed that with the predictor variables (family size, nature of job, and years in marriage) simultaneously entered into the regression model, each of them contributed significantly to the prediction of working 
mothers' job commitment. However, nature of job contributed mostly to job commitment $($ Beta $=.323, \mathrm{t}=$ $19.492, \mathrm{p}<.05)$.

This was successively followed by family size $($ Beta $=.251, \mathrm{t}=19.492, \mathrm{p}<.05)$ and years in marriage (Beta

$$
=.243, \mathrm{t}=
$$

$8.612, \mathrm{p}<.05)$.

\subsection{Testing of Hypothesis}

\subsubsection{Hypothesis One}

Ho1: There is no significant combined influence of family size, nature of job and years in marriage on working mothers' job commitment in public universities in South-West, Nigeria.

Table 4: Model Summary and Coefficients of the Multiple Regression Analysis for the Influence of Family Size, Nature of Job, and Years in Marriage on Working Mothers' Job Commitment

\begin{tabular}{|c|c|c|c|c|c|}
\hline $\begin{array}{l}\text { Source of } \\
\text { Variation }\end{array}$ & Sum of Squares & Df & Mean Square & $\mathrm{F}$ & Sig. \\
\hline $\begin{array}{l}\text { Regression } \\
\text { Residual } \\
\text { Total }\end{array}$ & $\begin{array}{l}4528.599 \\
14992.681 \\
19521.280\end{array}$ & $\begin{array}{l}3 \\
946 \\
949\end{array}$ & $\begin{array}{l}1509.533 \\
76.493\end{array}$ & 19.734 & $.000^{\mathrm{b}}$ \\
\hline
\end{tabular}

Dependent Variable: Job Commitment

a. Predictors: (Constant), Years in Marriage, Family Size, Nature of Job

Results in Table 4 were significant $\left(\mathrm{F}_{(3,946)}=19.734, \mathrm{p}<.05\right)$. The null hypothesis was consequently rejected in favour of the alternative hypothesis leading to the conclusion that there is a significant combined influence of family size, nature of job and years in marriage on working mothers' job commitment in public universities in South-West, Nigeria. Results further revealed that family size, nature of job, and years in marriage accounted for $18.3 \%$ of the variance in social adjustment (Adj. $\mathrm{R}^{2}=.183$ ).

\subsubsection{Hypothesis Two}

Ho2: Family size will not significantly influence the job commitment of working mothers in public universities in South-West, Nigeria.

Table 5: Coefficients of the Regression Analysis for the Influence of Family Size on Working Mothers' Job Commitment

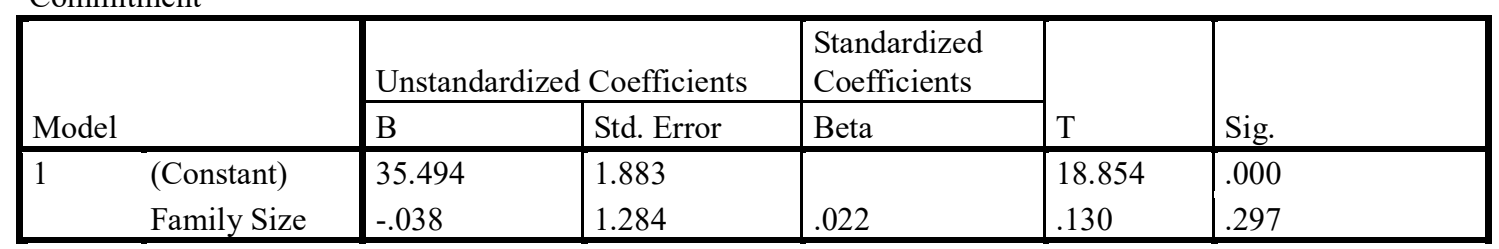

a. Dependent Variable: Job Commitment

Results in Table 5 were not significant $(\mathrm{t}=.130, \mathrm{p}>.05)$. The null hypothesis was consequently upheld leading to the conclusion that family size will not significantly influence the job commitment of working mothers in public universities in South-West, Nigeria.

\subsubsection{Hypothesis Three}

Ho3: Nature of job will not significantly influence the job commitment of working mothers in public universities in South-West, Nigeria. 
Table 6: Coefficients of the Regression Analysis for the Influence of Nature of Job on Working Mothers' Job Commitment

\begin{tabular}{|c|c|c|c|c|c|c|}
\hline \multirow{2}{*}{\multicolumn{2}{|c|}{ Model }} & \multicolumn{2}{|c|}{ Unstandardized Coefficients } & \multirow{2}{*}{$\begin{array}{l}\text { Standardized } \\
\text { Coefficients } \\
\text { Beta }\end{array}$} & \multirow[b]{2}{*}{$\mathrm{t}$} & \multirow[b]{2}{*}{ Sig. } \\
\hline & & $\mathrm{B}$ & Std. Error & & & \\
\hline 1 & $\begin{array}{l}\text { (Constant) } \\
\text { Nature of Job }\end{array}$ & $\begin{array}{l}16.486 \\
3.625\end{array}$ & $\begin{array}{l}2.286 \\
.114 \\
\end{array}$ & .334 & $\begin{array}{l}15.962 \\
7.475\end{array}$ & $\begin{array}{l}.000 \\
.000\end{array}$ \\
\hline
\end{tabular}

a. Dependent Variable: Job Commitment

Results in Table 6 were significant $(t=7.475, \mathrm{p}<.05)$. The null hypothesis was consequently rejected in favour of the alternative hypothesis. It was therefore concluded that nature of job significantly influenced the job commitment of working mothers in public universities in South-West, Nigeria.

\subsubsection{Hypothesis Four}

Ho4: Years in marriage will not significantly influence the job commitment of working mothers in public universities in South-West, Nigeria.

Table 7: Coefficients of the Regression Analysis for the Influence of Nature of Job on Working Mothers' Job Commitment

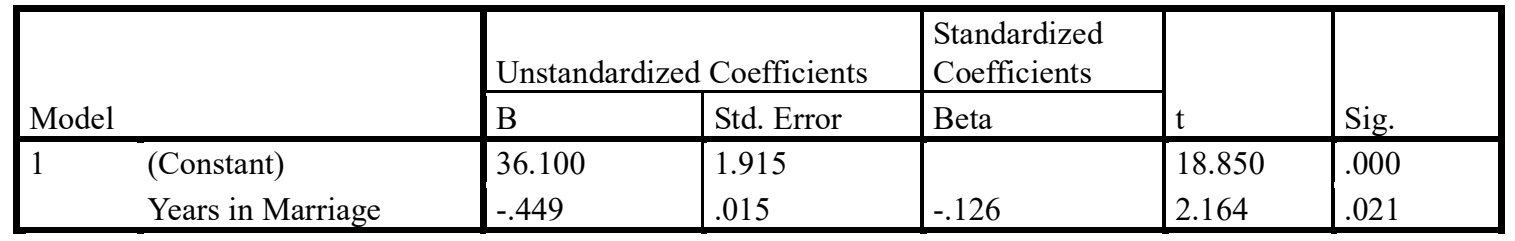

a. Dependent Variable: Job Commitment

Results in Table 7 were significant $(t=2.164, \mathrm{p}<.05)$. The null hypothesis was consequently rejected in favour of the alternative hypothesis. It was therefore concluded that years in marriage significantly influenced the job commitment of working mothers in public universities in South-West, Nigeria.

\section{5. DISCUSSION}

Research question one revealed that the job commitment of working mothers in public universities in SouthWest Nigeria is low. This is confirmed by Ugwu (2010) who stated that job commitment of women have remained poor due to the inadequacy of some needed facilities and non-implementation of the existing policies by some university management. This is not surprising because women as a whole handle dual tasks of working and caring for their families and in a country like Nigeria, it is very difficult for them to find a balance in their family and work domains when work-life balance is not supported by management. Unfortunately, these mothers still struggle to be committed to their jobs and at the same time try to handle the unending demands of a young child as well as other family responsibilities without receiving enough support from their organizations.

Analysis of research question two revealed that of all the variables studied, that nature of job contributed mostly to the working mothers' job commitment in public universities in South-West, Nigeria. The reason for this is not far-fetched. Teaching and non-teaching staff in public universities in South-West, Nigeria have different work assignments. While teaching staff have more flexibility in work schedule, the non-teaching staff face more regimented schedule hence, this may contribute to their job commitment.

The first hypothesis stated that there is no significant combined influence of family size, nature of job and years in marriage on working mothers' job commitment in public universities in South-West, Nigeria. However, this hypothesis was rejected because the outcome of the analysis show that they actually jointly influenced working mothers' job commitment. This present finding agrees with Gani and Ara (2010) who discovered that years in marriage, marriage situation and family background can affect commitment. This finding agrees with Azim, Haque and Chowdhury (2013) that marriage makes one value one's work and become better adjusted hence working mothers with more years in marriage are more stable and are able to develop strategies to prevent work family conflict. On nature of job, Oladosu and Adeniji (2015) compared the level of job satisfaction and job 
commitment between female academic and non-academic staff of public universities in Nigeria, and observed that female teaching staff are more involved in their jobs unlike their non-teaching counterparts that quit on short notices and go in search of better jobs. The reason for this could be due to the fact that female non-teaching staff may experience more work-family conflict than the teaching staff due to lack of flexibility in their job schedule which invariably affect their job commitment. Noonan, Rippeyoung and Glass (2007) also discovered that women in non- teaching jobs experience more role conflict than their teaching counterparts probably because they work more number of hours every week, have inflexible work schedules, frequent occurrence of overtime, difficult supervisors and work atmosphere that is not conducive and supportive of work and family life. Other studies confirming the above findings are Amos, Acquah, Antwi and Adzifome (2015). Contrarily, Ajayi, Awosusi, Arogundade and Ekundayo (2011) did not see any influence of nature of job on job commitment of academic staff and non-academic staff. It is generally accepted that the higher the number of children, the greater job conflict and once a woman experiences conflict, commitment is affected. On that note, this study agrees with Moore (1995) who confirmed that women who are married and mothers of small children experience more home-work role conflict but Campell, Campell and Kernnard (1994) disagreed to this since in their studies they found that the age and number of children is not a good predictor of job commitment and the reason behind this outcome could be explained on the grounds that financial reasons motivate many women to work harder despite the ages and number of their children in order not to lose their sources of income.

The second hypothesis which stated that family size will not significantly influence working mother's job commitment in public universities in South-West Nigeria was accepted. The implication of this is that whether the family is small or large, it does not affect a working mother's job commitment. The reason for this could be that if the working mother gets enough organizational support in form of favourable policies like adequate maternity leave, child-care supportive policies, lactation breaks provision, flexible working time arrangements, university situated crèche and the support of her husband, she can adjust the demands of her family with her work and remain committed. This finding supports that of Kossek, Pichler, Bodner and Hammer (2011) and Reddy, Vranda, Ahmed, Nirmah and Siddaramu (2010) that organizations that are supportive of positive workfamily relationships based on the fact that organizations are hiring increasing number of workers who are bringing their family demands with them while on the job will assist such employees to be better committed and that the level of organizational support impact the job commitment of working mothers. Okereke (2004) findings reveal that age of the youngest child and number of children a woman has is not a viable predictor of her commitment to work.

The third hypothesis which stated that nature of job will not significantly influence the job commitment of working mothers in public universities in South-West, Nigeria was rejected. The result of data analysis showed that nature of job significantly influenced the working mother's job commitment. An explanation for this finding is that the type of job a working mother does such as teaching or non-teaching may likely influence the level of support received from the university, the extent of her experience of work-family conflict all which moderates her level of job commitment and observing the trend in public universities in Nigeria today, it becomes clearer that the teaching staff are at advantage over their non-teaching counterparts in terms of pay, working conditions and support. This position is in line with several studies like Anarfarta (2011); Yaacob and Long (2015); Mukhatar (2012); Gbenro and Agesin (2014); Aondoaver (2013); that workers in organizations tend to compare their efforts and gains in line with the support received from the organization and this comparison then gives rise to emotions, behaviours and commitment of the worker toward their job.

The fourth hypothesis stated that years in marriage will not significantly influence the job commitment of working mothers in public universities in South-West, Nigeria. However, the outcome of the analysis indicated that years in marriage actually influenced the job commitment of working mothers. This is in tandem with the earlier studies of Gani and Ara (2010). While researching on work-family conflict for working women, they came out with the conclusion that work-family conflict which adversely affects commitment for women is more pronounced in young women with less experience in marriage, with small kids than in elderly mothers who are experienced in marriage with older children. The studies of Moen and Yu (2000); Mirrowsky and Ross (2003); Bellewa and Frone (2005) and Azim, Haque and Chowdhury (2013) is in agreement with the above study which confirmed that working mothers with more years in marriage are more stable and are able to develop strategies to prevent work family conflict. It is so because it is generally believed that with the advance in age and maturity of mind, the adaptability of a person increases therefore elderly women who have been married for longer periods of time are able to adjust their role situations than younger ones who have less experience in marriage 
and are still currently nursing children.

\section{CONCLUSION}

The findings revealed that family size, years in marriage and nature of job jointly contributed significantly to working mothers job commitment. Specifically, nature of job was found to contribute mostly to their job commitment. Since teaching and non-teaching staff in public universities in South-West, Nigeria have different work assignments with teaching staff having more flexibility in work schedule than the non-teaching staff there is the likelihood that the non-teaching employees may have more regimented schedule which is likely to affect their job commitment. This have implications for university administration because, it is important that they encourage working mothers to become fully committed to their jobs by introducing flexibility in work scheduling and job descriptions to allow them have more autonomy in deciding how to carry out their duties especially those with young children. While family size did not have any significantly influence on working mother's job commitment, it was further discovered that the job commitment of working mothers in public universities in South-West, Nigeria is low, hence the need for the university management to cater for the welfare of working mothers based on their unique needs and situations. The University administration should make provision for family life educators that will give training to working mothers in form of seminars, workshops etc. that will assist them find coping strategies to balance work and family demands.

A future research on this topic can be extended to private universities in South-West Nigeria. Concentration of this work on public universities in South-West alone may limit the possibility of generalizing the result to other private universities in South-West and other universities in other geographical zones in Nigeria.

\section{References}

Adeboyeye, R. (2000). A practical approach to effective utilization and maintenance of physical facilities in secondary schools, In J. O. Fadipe \& E. Oluchukwu (eds). Education planning and administration in the 21st century. Ondo NIEPA.

Adekola, B. (2012). Impact of organizational commitment on job satisfaction: a study of

employees at Nigerian Universities. International Journal of Human Resources Studies, 2 (2), 1 - 17.

Ajayi, F., Ojo, S. \& Mordi, C. (2015). Work-Family Balance and Coping Strategies among Women: Evidence from Commercial Banks in Nigeria. European Journal of Business and Management, 7(2), 152 - 160.

Ajayi, M. (2013). Work-Family Balance and Coping Strategies among Women in the banking sector. Retrieved from: http://citeseerx.ist.psu.edu/viewdoc/download?doi=10.1.1.735.1416\&rep=rep1\&type=pdfwk-

Akpan, C. (2012). Resource management and job involvement among universities lecturers in South-South Nigeria. European Journal of Business and Social Sciences, 1(8), 12-22.

Aondoaver, U. (2013). Distributive justice, age and organizational citizenship behavior among non-teaching staff of Benue State University. International Journal of Psychology and Behavioural Studies, 3 (4), 77 - 85.

Arciniega, L. M., Gonzalez, L. (2011). What is the influence of work variables relative to other Variables

in the development of organizational commitment? Available: $\quad$ www.mamma.com

Austen, S. E. \& Birch, E. R. (2000). Family responsibilities and women's working lives. Retrieved: https://espace.curtin.edu.au/bitstream/handle/20.500.11937/42655/20883 downloaded stream 339.pdf?sequenc $\underline{\mathrm{e}=2}$. Accessed February 03, 2019.

Azim, M. T., Haque, M. M. \& Chowdhury, R. A. (2013). Gender, marital status and job satisfaction: an empirical study. International Review of Management and Business $\quad$ Research, 2 (2), $488-498$.

Beauregard, T. A. (2007). Family influence on the career life cycle, in M. Ozbilgin \& A. Malach Pines (Eds), Career Choice in Management and Entrepreneurship: a research companion. Pp. 101-126. 
Campbell, D. J. Campbell, K. M. \& Kennard, D. (1994). The effects of family responsibilities on the work commitment and job performance of non-professional women. Journal of Occupational and Organizational Psychology, $\quad 67,283-296$.

Erdheim, J, Wang, M. \& Zickar, M. J. (2006). Personality and individual differences. Human Resources Review. 41 (5), 959 - 970.

Farrell, D. \& Rusbolt, C. E. (1981). Exchange variables as predictors of job satisfaction, job commitment and turnover: the impact of rewards, costs, alternatives and investments. Organizational Behaviour \& Human Performance, 28, 78 - 95.

Gani, A. \& Ara, R. (2010). Work and family. Indian Journal of Industrial Relations. Available: http://www.freepatentcolumn.com/article/indian-journal- indianRelations/235631661.

Gbenro, B. A. \& Agesin, B. E. (2014). Withdrawal cognition among workers in distressed banks: roles of perceived organizational support and inequality. African Journal for Psychology and Social Science Issues, 17 (2),

Greenhaus, J. H. \& Powell, G. N. (2003). When work \& family collide: deciding between role demands. Organizational Behaviour \& Human Decision Process, 90,

Gupta, A. (2011). Organizational commitment - basic concepts \& recent developments. Available: www.mamma.com.

Kiyak, H.A. Namazi, K. H. \& Kahana, E. F. (2011). Job commitment and turnover among women working in facilities serving older persons. Available: $\quad$ http://roa.sagepub.com/content/19/2/223.abstract.

Kossek, E. E., Pichler, S., Bodner, T. \& Hammer, L. B. (2011). Workplace social support and work-family conflict: a meta analysis clarifying the influence of general and work- family specific supervisor and organizational support personnel. Personnel Psychology, 64 (2) $289-313$.

Lumley, E. J., Coetzee, M., Tladinyane, R \& Ferreira, N. (2011). Exploring the job satisfaction and organizational commitment of employees in the information technology environment. Southern African Business Review, 15 (1), 100 - 118.

Moore, D. (1995). Role Conflict: not only for women? a comparative analysis of 5 Nations. International Journal of Comparative Sociology. 36 (2).

Nawi, N. C., Ismail, M., Ibrahim, M. A. \& Raston, N. A. (2016). Job Satisfaction among academic and nonacademic staff in public universities in Malaysia: A review. International Journal of Business and Management, 11 (9), 148 - 153.

Noonan, M. C., Rippeyong, P. L. \& Glass, J. L. (2007). Does women's work commitment change after marriage and motherhood?. Retrieved from: workbabydraft-1-doc. Accessed July 7, 2018.

Okereke, N. C. (2004). The effect of family responsibility on the work commitment of professional women workers: An M.Sc. research report. Retrieved from: repository.unn.edu.ng. Accessed July 7, 2018.

Oladosu, C. T. \& Adeniji, A. A. (2015). Gender Influence on Job Satisfaction and Job Commitment among Colleges of Education Lecturers. Journal of Education and Practice, 6 (13), 162 - 165. 


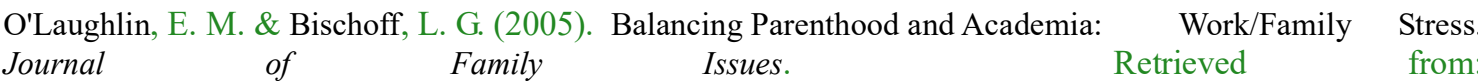
https://pdfs.semanticscholar.org/1cbd/5f02269038484f791ba168f6fa8485b5e39e.pdf2 005 .

Reddy, N. K., Vranda, M. N., Ahmed, A., Nirmala, B. P. \& Siddaramu, B. (2010). Work-life balance among married women employees. Indian Journal of Psychiatric Medicine, $32 \quad$ (2), $112-118$.

Sanders, W. (n.d). Job commitment: the influence of managerial behaviour. Retrieved from: http://arno.uvt.nl/show.cgi?fid=81804 Accessed February 03, 2019.

The Kerman English Multilingual Dictionary (2013).

Workplace Fairness Report (2019). Caregiving responsibilities discrimination. Retrieved from: https://www.workplacefairness.org/family-responsibilities-discrimination. Accessed February, 03, 2019.

Yaacob, M. \& Long, C. S. (2015). Role of occupational stress on job satisfaction.

Mediterranean Journal of Social Sciences, 6 (2), $81-87$.

Ngozi Caroline Uwannah (HND '96; MPP 2006; B.Sc (Ed.) 2016; PhD 2017) has a Higher National Diploma (HND) in Secretarial Administration in 1996 from Federal Polytechnic Nekede, Owerri; B.Sc (Ed.) in Business Education from Babcock University, Ilishan-Remo, Ogun State Nigeria in 2016; Master's Degree in Personnel Psychology (MPP) in 2006 and PhD in Applied Psychology (Personnel) from Olabisi Onabanjo University, AgoIwoye, Nigeria in 2017. Dr. Uwannah has served as Executive Secretary at the Bursary Department, lectured in the General Education Studies Department of Babcock University and currently a Lecturer at the Department of Education, Babcock University. She has taught for over 12 years at the undergraduate level and published several scholarly articles in reputable journals both at local and international levels. She is currently a fellow at the Institute of Strategic Human Resource Management, Nigeria and a member of Babcock University Gender and African Studies Group. 